\title{
IDENTIFICATION AND MONITORING OF NOISE SOURCES OF CNC MACHINE TOOLS BY ACOUSTIC HOLOGRAPHY METHODS
}

\author{
Jerzy Józwik \\ 1 Department of Production Engineering, Mechanical Engineering Faculty, Lublin University of Technology, \\ 36 Nadbystrzycka Str., 20-816 Lublin, Poland, e-mail: j.jozwik@pollub.pl
}

Received: 2016.04.15

Accepted: 2016.05.10

Published: 2016.06.01

\begin{abstract}
The paper presents the analysis of sound field emitted by selected CNC machine tools. The identification of noise sources and level was measured by acoustic holography for the 3-axis DMC 635eco machine tool and the 5-axis vertical machining centre DMU 65 monoBlock. The acoustic holography method allows precise identification and measurement of noise sources at different bandwidths of frequency. Detection of noise sources in tested objects allows diagnosis of their technical condition, as well as choice of effective means of noise reduction, which is highly significant from the perspective of minimising noise at the $\mathrm{CNC}$ machine operator workstation. Test results were presented as acoustic maps in various frequency ranges. Noise sources of the machine tool itself were identified, as well as the range of noise influence and the most frequent places of reflections and their span. The results of measurements were presented in figures and diagrams.
\end{abstract}

Keywords: noise, acoustic holography, monitoring, CNC machine tools, machining.

\section{INTRODUCTION}

Identification of noise sources and level plays an important part in production processes. In contemporary flexible manufacturing systems one of the most commonly used technologies is subtractive machining. Subtractive machining processes are performed with $\mathrm{CNC}$ machine tools. Such machines generate noise; its identification and estimation of sources and level plays vital part, both from the perspective of work safety and observance of safety standards $[3,8,17]$. Noise increases risk of putting the machine operator's health in danger. It is taken into account throughout the evaluation of the occupational risk of the machine tool operator $[2,8,16,21-22,28]$. The source of noise in machine tools are: drives, mechanisms transmitting the drive to the executive systems, clutches, brakes and the physical machining process itself [18-20, 23-26, 28]. Identification of the acoustic and vibro-acoustic signal is also used for estimating the condition and monitoring the bearings. The work [12] discusses the influence of the defect of design and technology of the bearing on generating the vibro-acoustic signals of machines and mechanisms. It was determined that defects of technology result in vibrations and noise of low frequency (from $50 \mathrm{~Hz}$ to $1500 \mathrm{~Hz}$ ) and of very high frequency $(1500 \mathrm{~Hz} \div 10000 \mathrm{~Hz})$. Also, evaluation of acoustic emission applicability to tool condition monitoring in turning were presented in [7,9] and in the light of prognoses presented in paper [6], it will be one of the developing trends in diagnostics of machines, tools and physical machining process. In order to achieve maximum values of quality indexes of a product, frequent monitoring and quick diagnostics is necessary $[10,13,14,30]$.

One of identification techniques of noise sources is acoustic holography. It is a modern method of analysis of the sound field, allowing precise location and identification of sound sourc- 
es $[4,5,12,15,26,29,30]$. It is applied, inter alia, in order to reduce noise and optimize its level in acoustic power measurements and spectral composition of noise emitted by tested objects. The aim of acoustic holography is setting spatial illustration of the sound field, on the basis of division of acoustic pressures, measured in the measuring space [23, 27, 29]. Recognition of the range and place of sound field, as well as the level of noise will allow avoiding putting the worker in danger and will let taking steps aiming at noise reduction $[3,6-8,28]$.

The aim of the tests was the analysis of the sound field emitted by selected CNC machine tools in the machining test-run inspection. Employed holographic analysis allowed measuring the levels as well as identification and location of main noise sources emitted by CNC machine tools. Identification of CNC machine tool noise sources is necessary to establish effective and successful methods of noise reduction at the workstation, which use the CNC machine tools, as well as throughout the evaluation of the occupational risk at the specific workstation.

\section{METHODS}

Acoustic holography is based on the two-dimensional Fourier transformation of the sound field [26] which results in the representation of the sound field in the domain of spatial frequencies (i.e. wave numbers) (Figure 1).

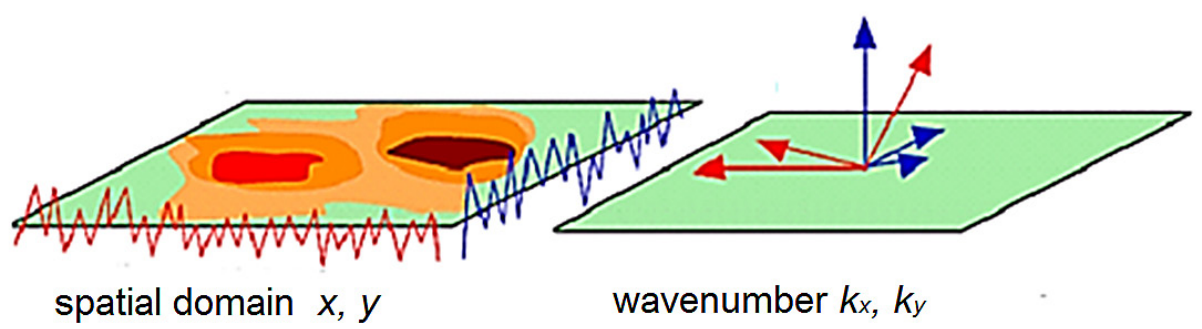

Fig. 1. Move from the spatial domain $x, y$ to wave numbers $k_{x}, k_{y}$, as a result of two-dimensional Fourier transformation [1]

A detailed study devoted to acoustic holography was presented in papers $[4,5,11,15,20,24,26]$. Transformation of the sound field from the spatial domain $\mathrm{p}\left(\mathrm{x}, \mathrm{y}, \mathrm{z}_{\mathrm{k}}\right)$, measured in plane with coordinate $\mathrm{z}_{\mathrm{k}}$, to the representation in the wave numbers domain $\mathrm{P}\left(\mathrm{k}_{\mathrm{x}}, \mathrm{k}_{\mathrm{y}}, \mathrm{z}_{\mathrm{k}}\right)$ may be calculated from dependence (1) [5]:

$$
P\left(k_{x}, k_{y}, z_{k}\right)=\iint_{-\infty}^{+\infty} p\left(x, y, z_{k}\right) e^{j\left(k_{x} x+k_{y} y\right)} d x d y
$$

Sound field $\mathrm{P}\left(\mathrm{k}_{\mathrm{x},}, \mathrm{k}_{\mathrm{y}}, \mathrm{z}\right)$ in any plane with coordinate $\mathrm{z}$ (parallel to the measurement plane) equals (2):

$$
P\left(k_{x}, k_{y}, z\right)=P\left(k_{x}, k_{y}, z_{k}\right) e^{-j k_{z}\left(z-z_{k}\right)}
$$

Accordingly, the sound field in the $\mathrm{x}, \mathrm{y}$ domain in any plane with the $\mathrm{z}$ coordinate can be set by the inverse Fourier transform [26] (3):

$$
p(x, y, z)=\frac{1}{4 \pi^{2}} \iint_{-\infty}^{+\infty} P\left(k_{x}, k_{y}, z_{k}\right) e^{-j\left(k_{x} x+k_{y} y+k_{z}\left(z-z_{k}\right)\right.} d k_{x} d k_{y}
$$

The results of the analysis are the acoustic pressure maps $\mathrm{p}(\mathrm{x}, \mathrm{y}, \mathrm{z})$ in planes parallel to the measurement plane (e.g. in planes of tested objects). In professional literature there are no papers on identification and location of noise sources in CNC machine tools with the use of acoustic holography. Despite different methods of evaluation of the sound field distribution being employed, acoustic holography usage in machine tools was not found in literature. This led authors to attempt to apply acoustic holography in diagnostics of noise sources generated by $\mathrm{CNC}$ machine tools and analyse advantages of the used method. 
a)

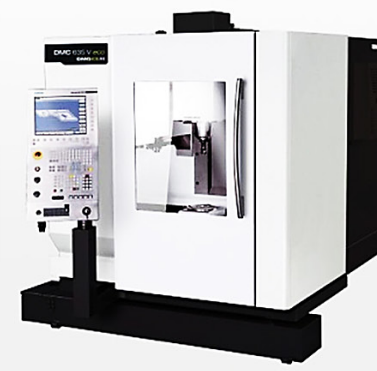

b)

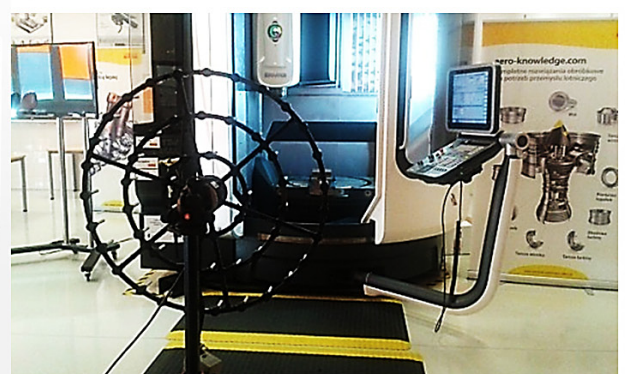

c)

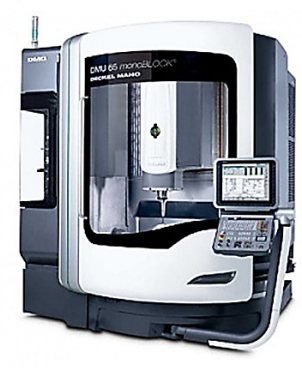

Fig. 2. Measurement stands: a) DMC 635eco milling machine, b) TL-AHW.18.1 LMS CircuitIrregularArray matrix to acoustic holography, c) DMU 65 monoBlock machine tool

Holographic measurements were conducted at two CNC machine tool stands: 3-axis DMC 635eco milling machine and DMU65 monoBlock 5-axis machining centre (Fig. 2).

Holographic measurements were conducted with the use of TL-AHW.18.1 LMS CircuitIrregularArray acoustic camera, including 56 standard microphones - PCB130E22, multi-channel signal analyzer Siemens LMS Scadas Mobile and specialist HD AcousticCamera software. Sampling frequency of the signal equalled $12.8 \mathrm{kHz}$ - for DMC 635eco milling machine and $25.6 \mathrm{kHz}$ - for the DMU 65 monoBlock vertical machining centre. It is equivalent to the analysis range, respectively: $6.4 \mathrm{kHz}$ and $12.8 \mathrm{kHz}$. Measuring time was $10 \mathrm{~s}$.

Tests were conducted in the machining conditions during the machining test-run inspection, when the effects on the machine's operator are of the highest value. The object of machining was a workpiece made of structural steel C45. During the DMC 635eco milling machine work, constant parameters of the technology machining were implemented: machining speed $\mathrm{v}_{\mathrm{c}}=150 \mathrm{~m} /$ min, depth of cut $a_{p}=1 \mathrm{~mm}$, feed motion speed $\mathrm{v}_{\mathrm{f}}=1200 \mathrm{~mm} / \mathrm{min}$. For the DMU65monoBlock 5-axis machining centre parameters were: depth of cut $\mathrm{a}_{\mathrm{p}}=2 \mathrm{~mm}$, machining speed $\mathrm{v}_{\mathrm{c}}=300 \mathrm{~m} /$ min, value of the feed motion speed $v_{f}=1200$ $\mathrm{mm} / \mathrm{min}$. The acoustic camera was set 3 meters in front of the machine.

\section{RESULTS}

Fig. 3a and $3 \mathrm{~b}$ show time representation of registered acoustic signals, emitted by the tested machine tools. Vertical lines mark the representative "time windows" of the signal, which were holographically analysed in detail.

Fourier spectrum of analysed parts of acoustic signal was presented in Figures $4 \mathrm{a}$ and $4 \mathrm{~b}$. Figure 5 presents time and frequency representation (spectrogram) of the registered signals.

Holographic analysis of the sound field was conducted with the use of specialist software HD AcousticCamera. Results of the analysis were presented as acoustic maps in Figures $6 \div 15$. Frequency range was selected basing on spectra of the analysed signals in such a way to comprise a great range of bandwidth of examined signal. Frequency ranges of analysis were marked on spectrums by vertical lines under each acoustic map. a)

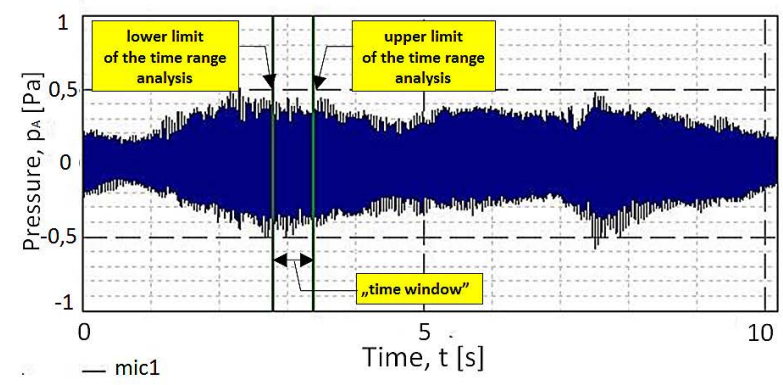

b)

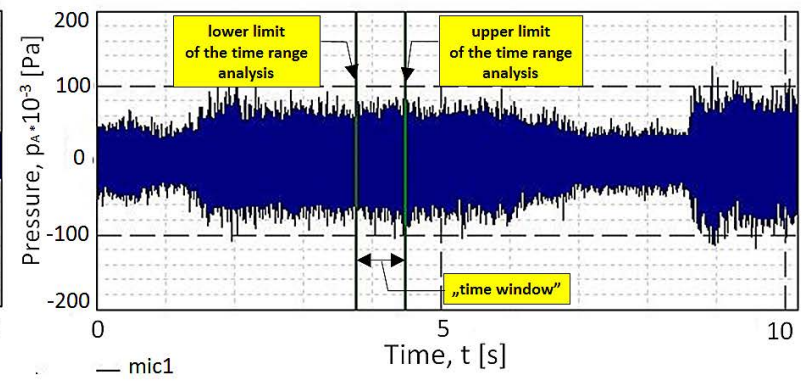

Fig. 3. Time representation of the acoustic signal, registered during the measurement at a stand, a) DMC 635 milling machine, b) DMU 65 Mono Block milling machine 
a)

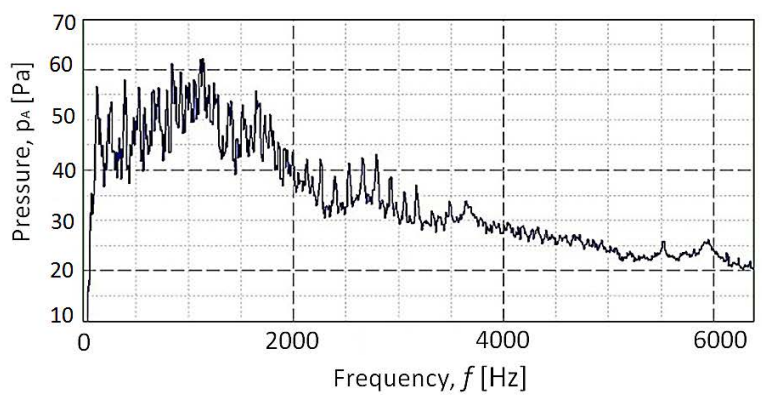

b)

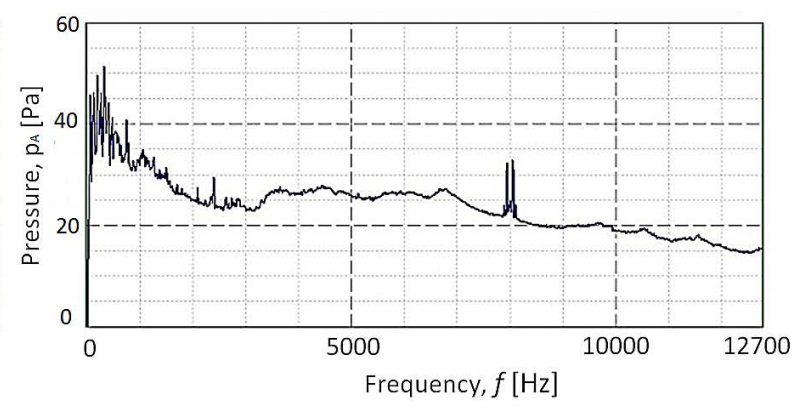

Fig. 4. Fourier spectrum of analysed acoustic signals emitted by milling machine: a) DMC 635eco, b) DMU 65 monoBlock

a)

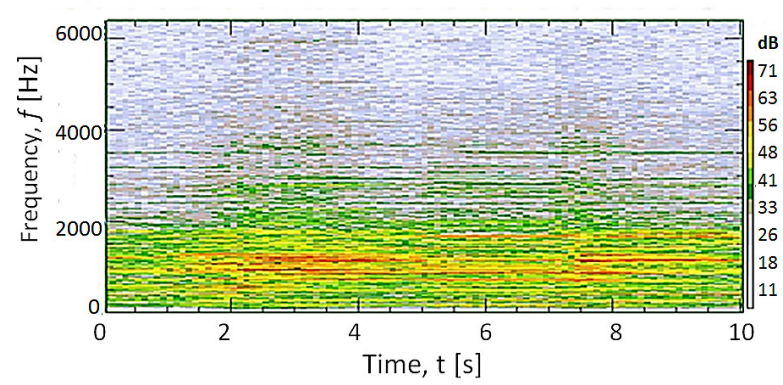

b)

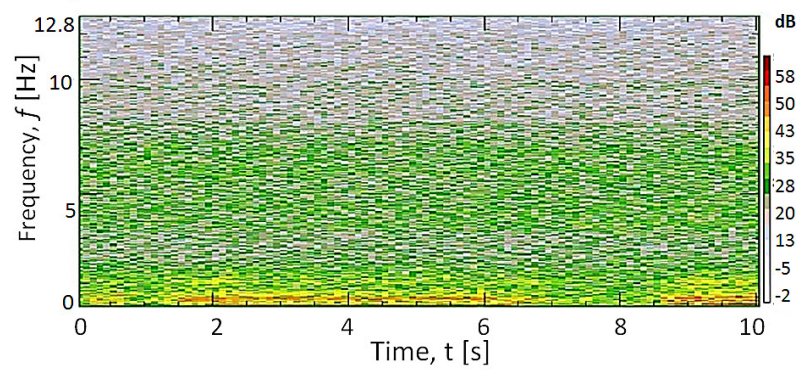

Fig. 5. Spectrogram of the acoustic signal registered during the measurement at the milling machine stand: a) DMC 635eco, b) DMU 65 monoBlock

Figure 5a presents the spectrogram of the acoustic signal registered at the DMC 635eco machining stand and Figure $5 \mathrm{~b}$ presents the proper spectrogram of the vertical 5-axis DMU 65 monoBlock machining centre.

\section{HOLOGRAPHIC ANALYSIS OF THE DMC 635ECO MILLING MACHINE}

Figure 6 presents results of the holographic analysis of the DMC 635eco milling machine in the $820 \div 1320 \mathrm{~Hz}$ bandwidth, including maximal frequency peaks in spectrum of the analysed signal. The main part of energy of the measured acoustic signal is accumulated in this bandwidth. The obtained map shows (Fig. 6) that the source of noise in this bandwidth are the functional subassemblies located in the top part of the milling machine case. These are sources of the main move drive, tool magazine and the tool changer, open machine case and door of the tested milling machine, as well as their vibrations. Maximal level of noise in the analysed bandwidth was 88dBA.

Figure 7 presents acoustic map in the frequency range $1320 \div 1610 \mathrm{~Hz}$. The source of noise in this range are functional subassemblies of the machine, such as: systems of the machine table drives in $\mathrm{X}$ and $\mathrm{Y}$ axes, as well as the chip management system, located in the lower part of the DMC 635eco milling machine. Maximal noise level in analysed frequency range was $76 \mathrm{dBA}$.

Figure 8 presents result of the holographic analysis in the frequency range $1620 \div 1840 \mathrm{~Hz}$. Vibrations of the machine door, mounted on hinges, and the noise generated during machining, coming out through the gaps between the door and the machine's case are the located sources of noise of the $76 \mathrm{dBA}$ level. The source of noise in this bandwidth is also the reflection from the widow of the room and the ceiling, which is clearly presented in Figures 8 and 9.

In the bandwidth outside the main peaks $1840 \div 5280 \mathrm{~Hz}$, acoustic map (Fig. 9) shows a few sources of noise connected with the same milling machine, as well as with a number of reflections from the surface of the room. The source of noise in this range, originating in the milling machine, is the top part of the case, the gap between the door and the case, as well as the machining process itself. Additionally, the map illustrated the reflections originating from the floor, window and the ceiling. The level of noise sources in this range equalled about $70 \mathrm{dBA}$. 


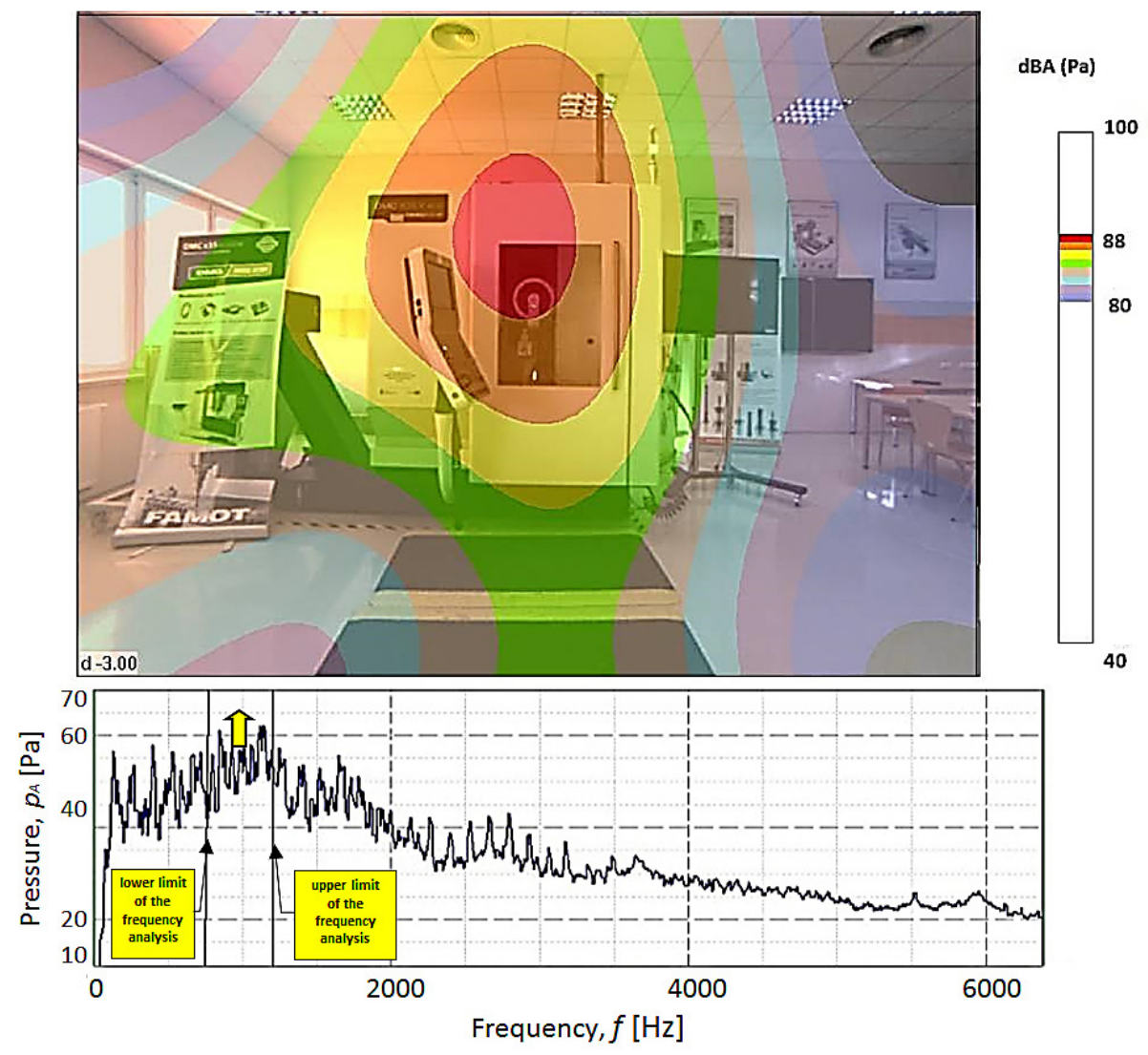

Fig. 6. Result of the holographic analysis of the DMC 635eco milling machine at $820 \div 1320 \mathrm{~Hz}$ frequency

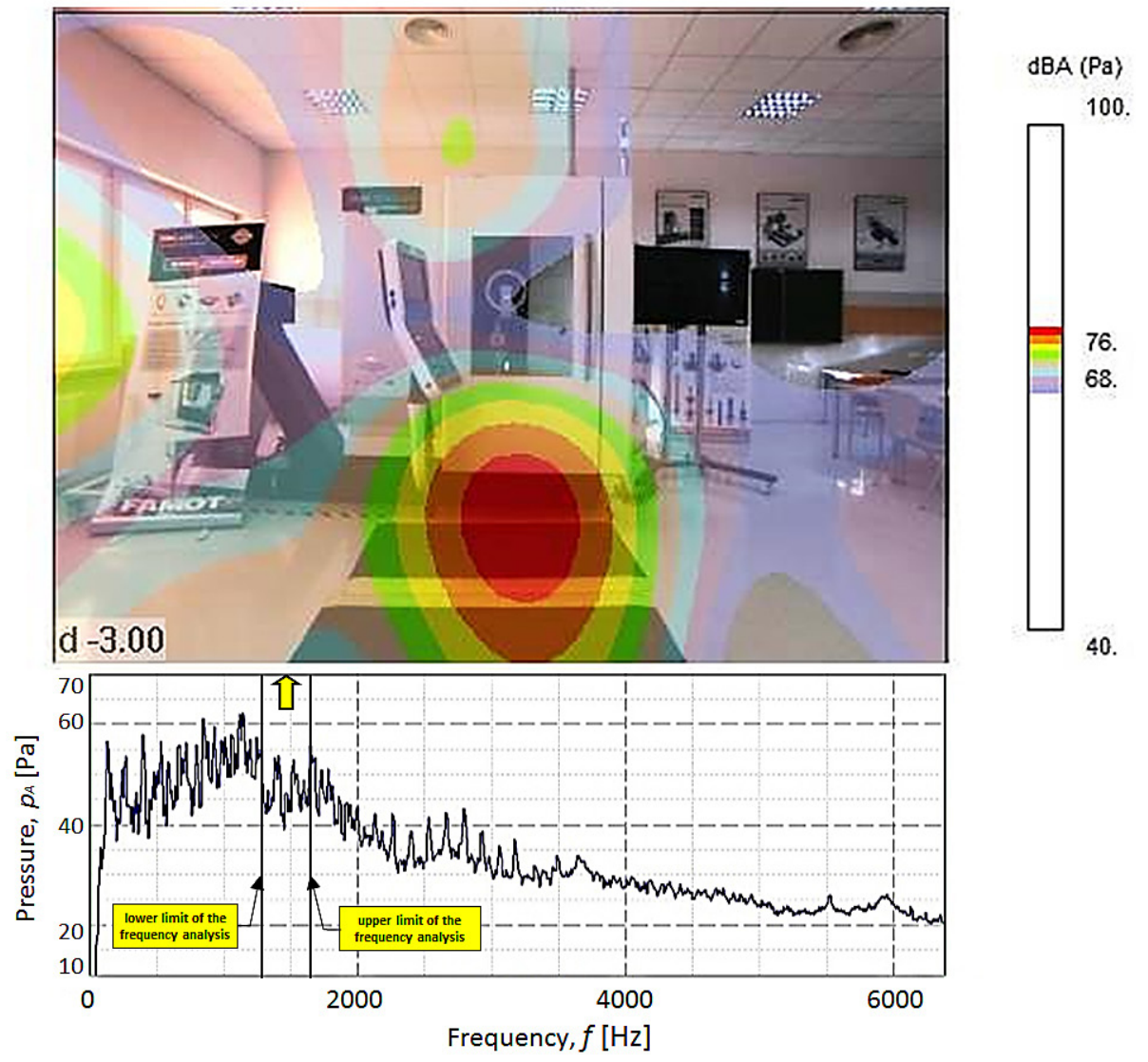

Fig. 7. Result of the holographic analysis of the DMC635eco milling machine in the range $1320 \div 1610 \mathrm{~Hz}$ 

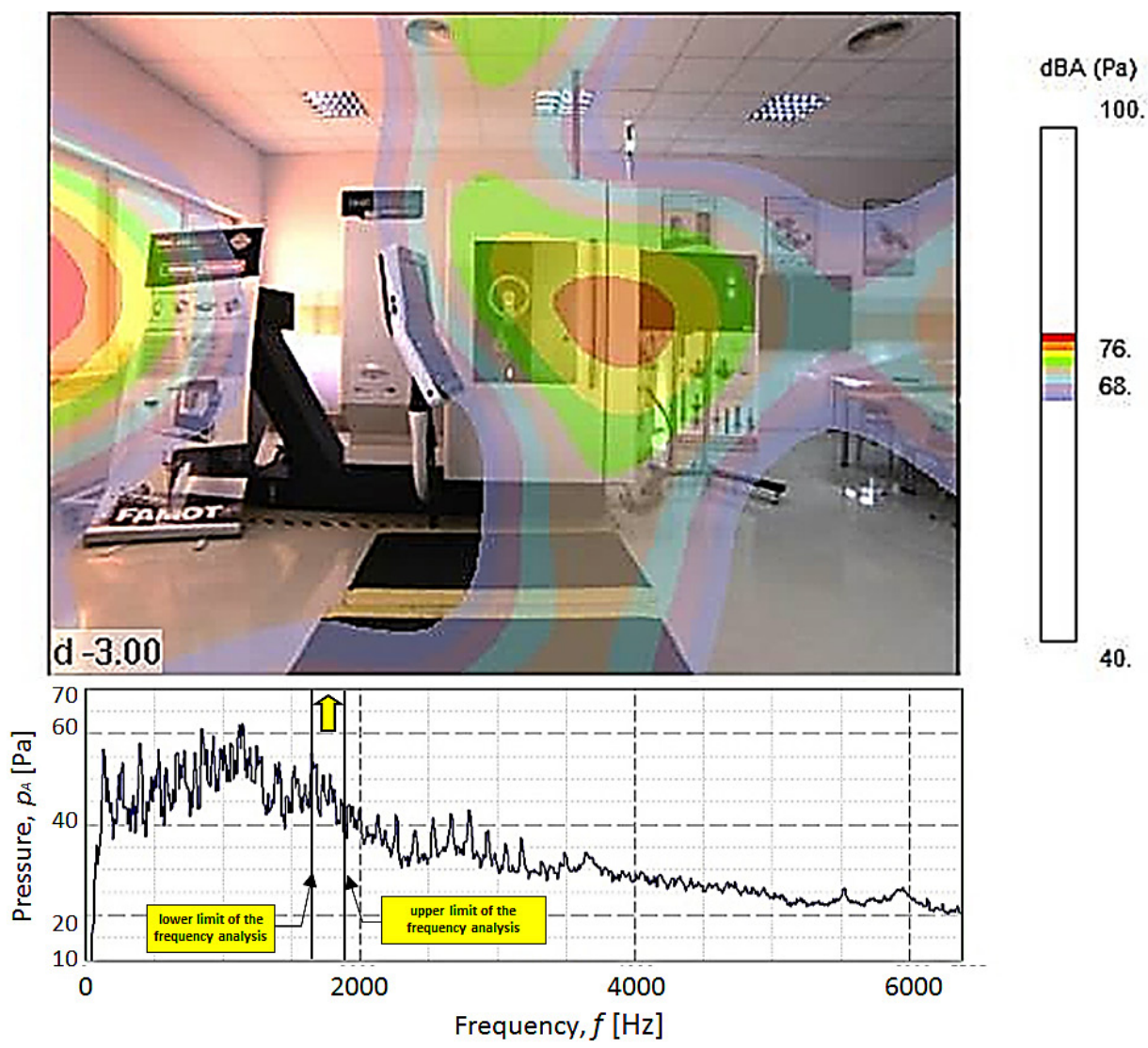

Fig. 8. Result of holographic analysis of the DMC 635 milling machine in the frequency rage $1620 \div 1840 \mathrm{~Hz}$
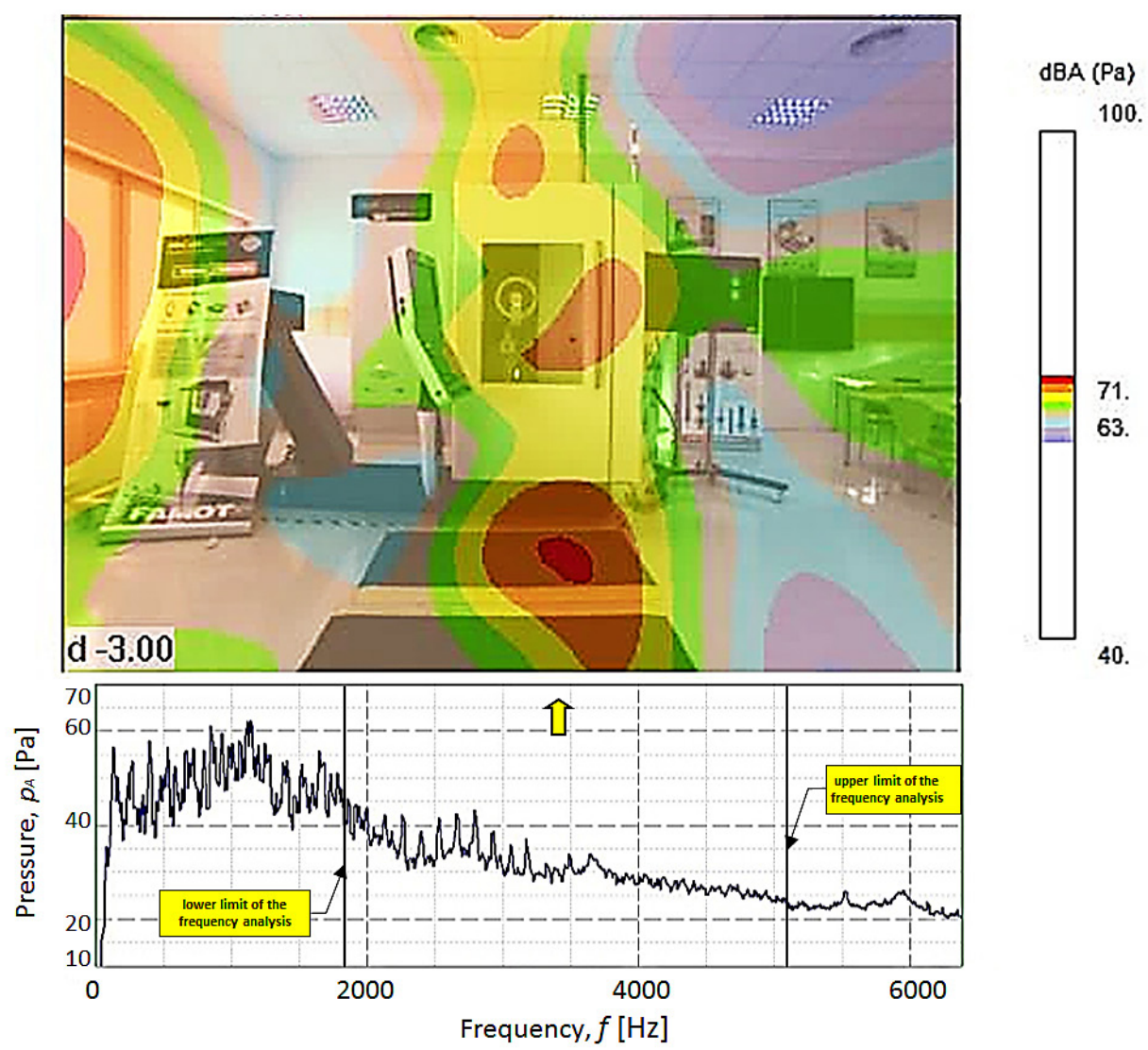

Fig. 9. Result of holographic analysis of the DMC 635 milling machine in the frequency rage $1840 \div 5280 \mathrm{~Hz}$ 


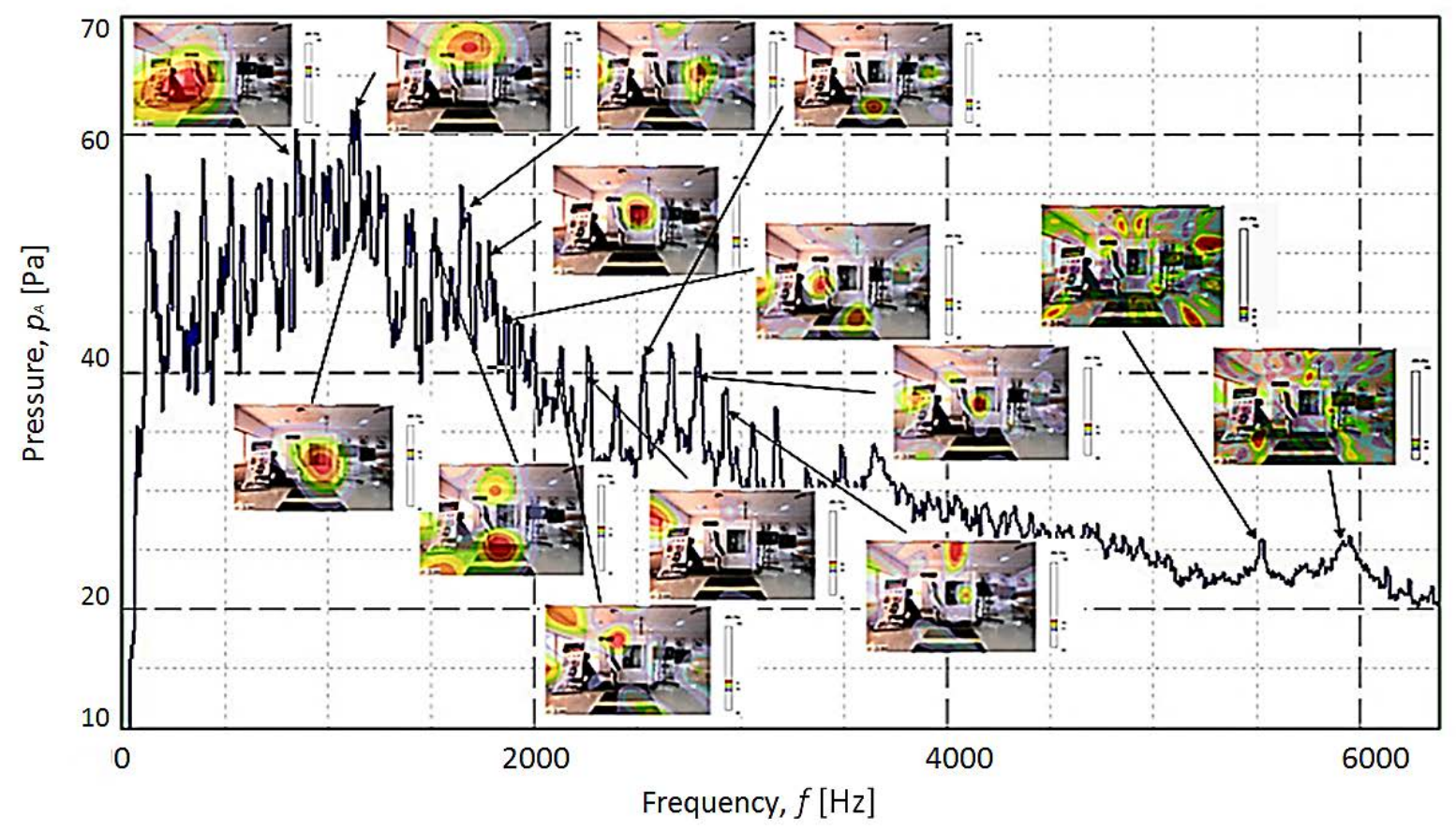

Fig. 10. Set of results of analysis of DMC 635eco milling machine acoustic holography in restricted bandwidths

Figure 10 presents acoustic maps for DMC 635 milling machine in restricted frequency ranges corresponding to characteristic spectrum peaks. They illustrate a number of noise sources connected with the milling machine itself, as well as with numerous reflections from the surface of the room.

Detailed analysis of DMC 635eco milling machine acoustic maps of specific restricted frequency ranges allows precise identification of all noise sources and location of reflections, as well as the evaluation of the range of their influence at the workstation of $\mathrm{CNC}$ machine tool.

\section{HOLOGRAPHIC ANALYSIS OF THE 5-AXIS DMU 65 MONOBLOCK MACHINING CENTRE}

Figure 11 presents the results of the holographic analysis of the sound field emitted by the DMU 65 monoBlock milling machine in the full bandwidth $(0 \div 12.8 \mathrm{kHz})$. The main source of noise at the level of $75 \mathrm{dBA}$ is the noise originating from the machining area, coming out through the gap between the door and the machine's case. The high level of noise, of the very high range of influence, was registered also near the steering system of the milling machine. The influenced area included the whole workstation of the machine tool operator, at which the programming works are conducted. The operator is exposed to the extensive noise. The level of noise registered in this area is $73 \mathrm{dBA}$.

Figure 12 presents acoustic map for the frequency range covering maximal spectrum peaks in restricted, low-frequency range $150 \div 850 \mathrm{~Hz}$. The main source of noise of $74 \mathrm{dBA}$ level is located near the interface of steering mechanism, that is, at the workstation of the programming operator of the machine tool. It turns out that for the analysed range of frequencies the source of noise and its range of influence is clearly defined. Evidently located noise sources at the operator's workstation allow taking proper action minimizing the operator's exposition to noise by organizing procedures, suggestions, and protection methods.

Allowing for the results of the holographic analysis presented in Figure 12, it is advised to minimize the time which operator spends in front of the steering panel of the machine tool, and in case of extensive work in the identified area - to use the hearing protection.

Figure 13 presents the result of the noise holographic analysis of the vertical DMU 65 monoBlock machining centre in the bandwidth $150 \div 7000 \mathrm{~Hz}$. In the analysed frequency part, the main source of noise at the machining workstation of DMU 65 monoBlock is the noise coming through the gap between the door and the milling machine's case, resulting from the physical process of milling. The level of registered noise in this bandwidth equalled $70 \mathrm{dBA}$. 


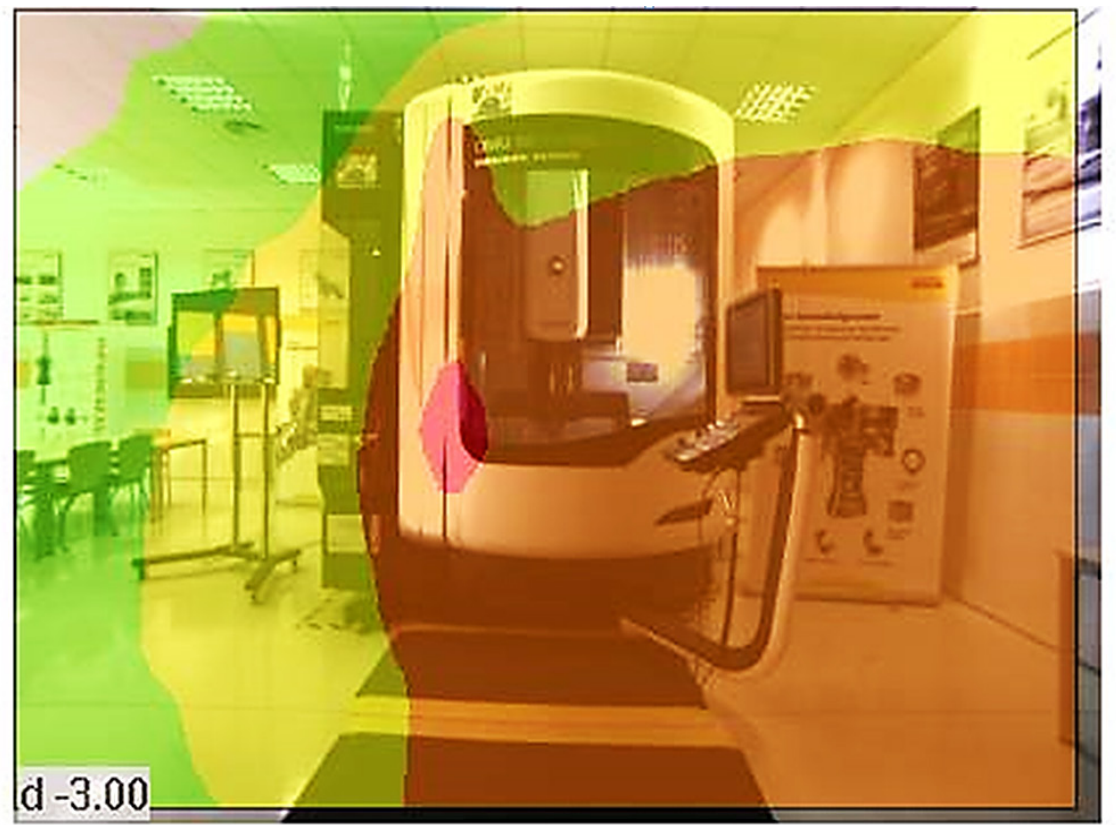

dBA $\{\mathrm{Pa}\}$

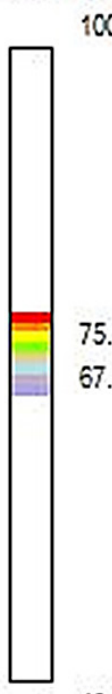

Fig. 11. Result of holographic analysis of the DMU 65 milling machine in the full bandwidth of analysed signal $(0 \div 12.8 \mathrm{kHz})$

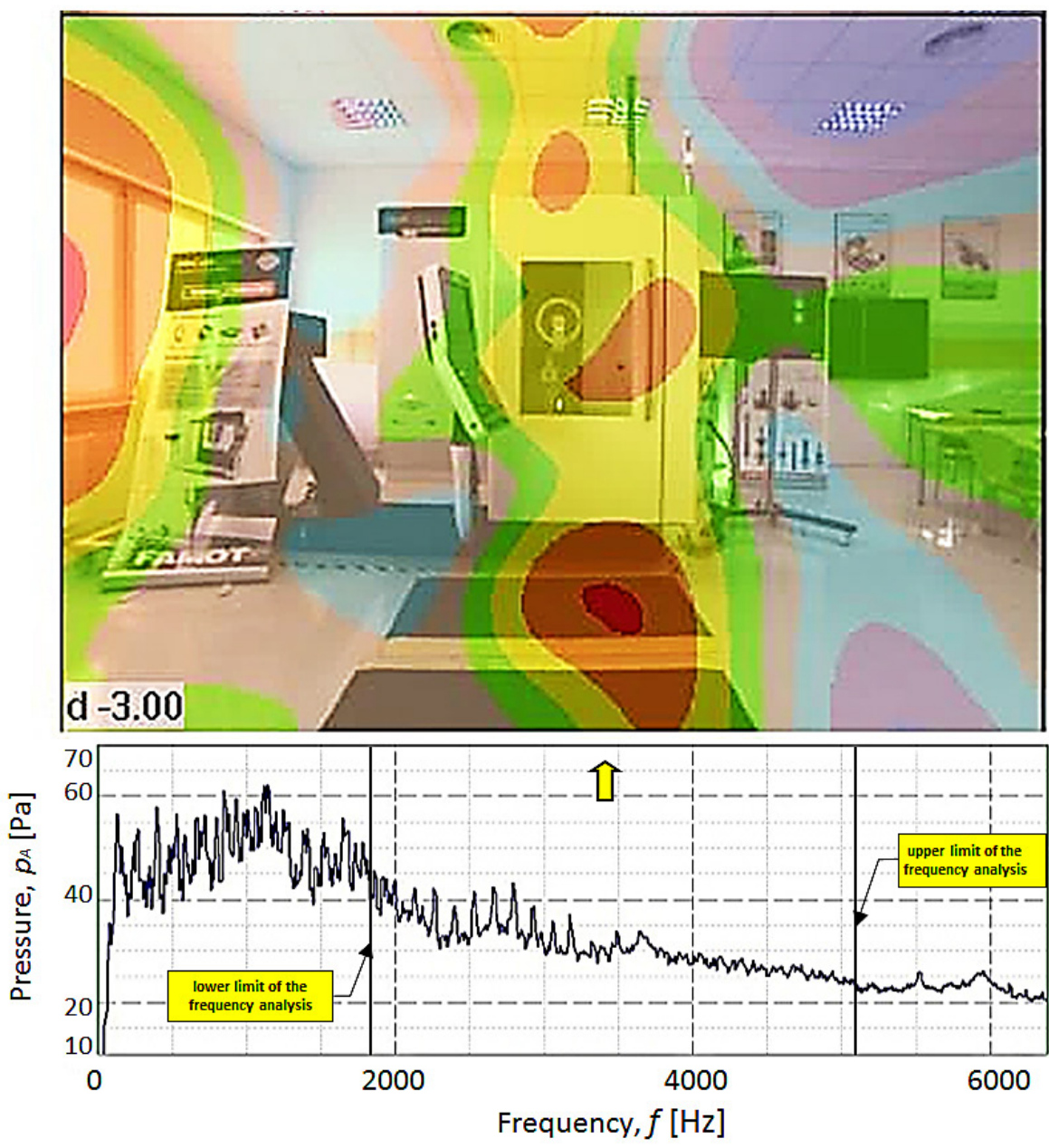

Fig. 12. Result of the holographic analysis of DMU 65MonoBlock milling machine in the bandwidth $150 \div 850 \mathrm{~Hz}$, covering maximal spectrum peaks of the analysed acoustic signal 


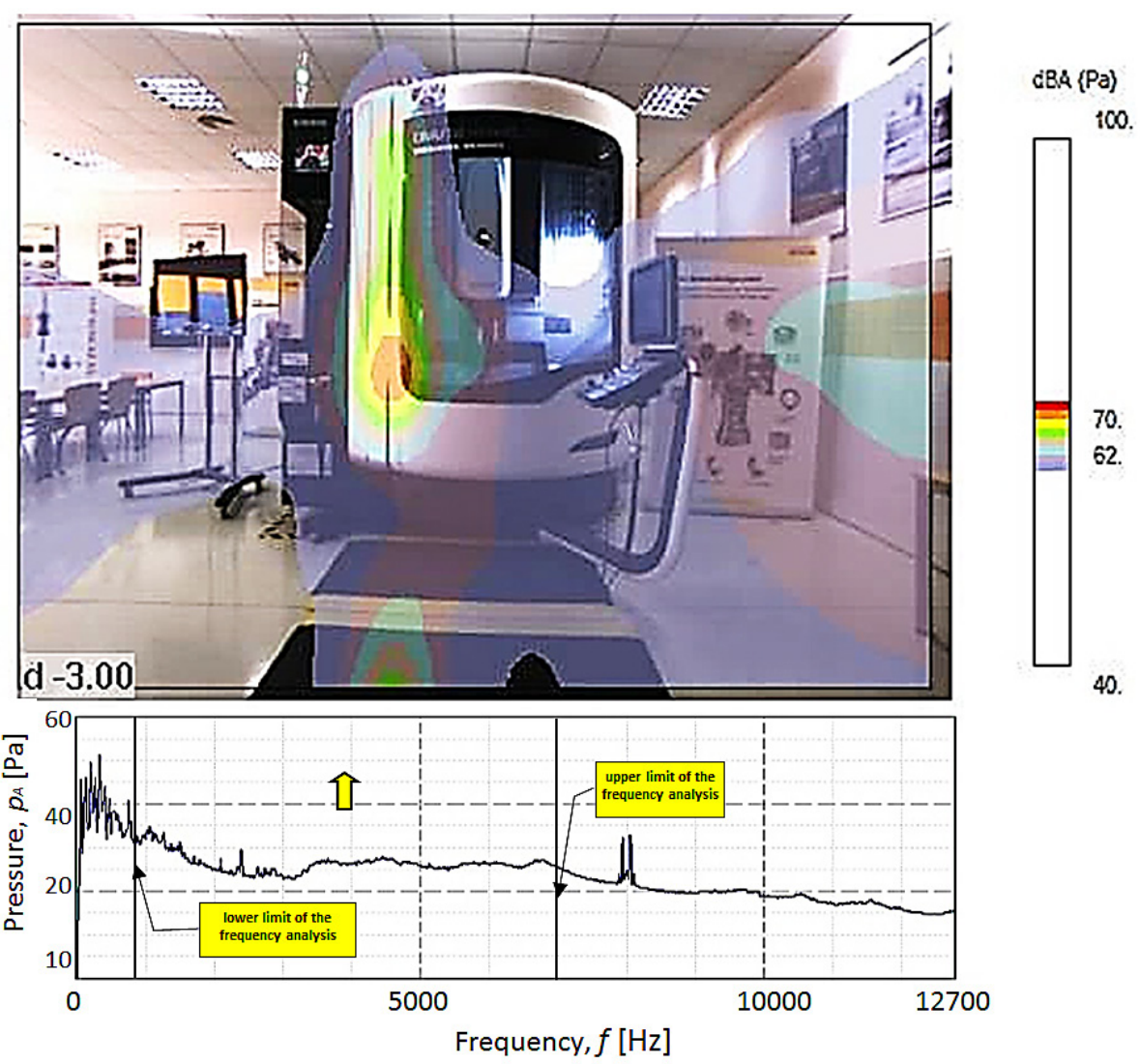

Fig. 13. Result of the holographic analysis of the DMU 65 monoBlock milling machine in bandwidth $850 \div 7000 \mathrm{~Hz}$
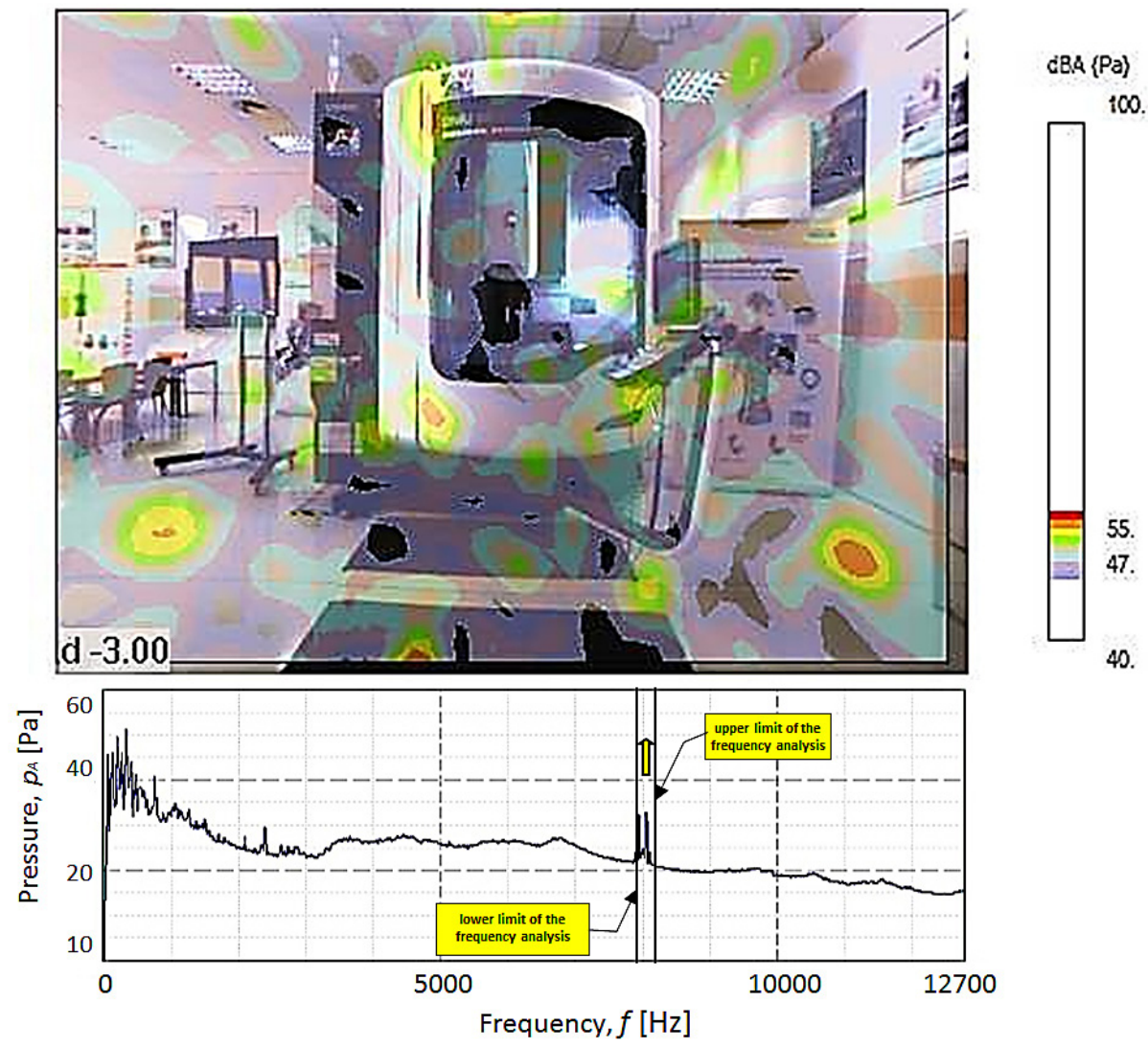

Fig. 14. Result of the holographic analysis of the DMU 65 monoBlock milling machine in bandwidth $7900 \div 8100 \mathrm{~Hz}$ 
Characteristic spectrum peaks at the high frequency on the level near $8 \mathrm{kHz}(7900 \mathrm{~Hz} \div 8100 \mathrm{~Hz})$ are the result of the acoustic signal reflections and interference, presented in Figure 14. Registered sources of reflections reach relatively low values of noise, equalling $50 \div 55 \mathrm{dBA}$.

Figure 15 presents acoustic maps for the DMU 65 monoBlock in narrow range of frequencies corresponding to characteristic spectrum peaks. They illustrate a number of noise sources connected both, with the milling machine itself, and with numerous reflections from the surfaces of the room.

Results of the acoustic holography analysis of the DMU 65 monoBlock milling machine, presented in Figure 15, show that for low frequencies the influence range includes the biggest areas of noise influence of high levels, near or exceeding the values of allowable levels. In higher frequencies the areas of noise influence fall clearly, and their level drops. For the very high frequencies of the holographic analysis, acoustic maps allow identifying the noise reflections, their area of influence and values. The level of noise reflections is far lower and forms at the medium level of 50\% noise registered in low bandwidth.

\section{CONCLUSIONS}

Acoustic holography analysis of the tested machine tools DMC 635 and DMU 65 Mono Block allowed identification and evaluation of the lev- els of a number of noise sources emitted by tested machine tools in the machining test-run inspection. The sources were connected both with machine tools themselves, as well as the reflections from the ceiling, walls, floor and windows of the room, in which the machining was performed. The analysis was conducted in various bandwidths, both wide (e.g. Fig. $6 \div 9$, Fig. $11 \div 13$ ) as well as narrow spectrum ranges (Fig. 10, Fig. 14, Fig. 15). For the DMC 635 eco milling machine the basic source of noise, connected with spectrum peaks in the lower bandwidth (range $0.8-1.3 \mathrm{kHz}$ ), was located in the top part of the milling machine (open milling machine's case) (Fig. 6). The level of noise in this range was $88 \mathrm{dBA}$. For the 5-axis DMU 65 Mono Block machining centre, the holographic analysis in the full bandwidth of the analysed signal allowed identification, as the main source of noise, drive assemblies and the physical process of machining. Noise goes through the gaps between the door and the milling machine's case (Fig. 10) and includes a wide influence area. High level of noise was observed also in the big area including the steering workstation of the machine tool. Measured level of noise equalled $74 \div 75 \mathrm{dBA}$. The noise source connected with spectrum maxima was located in the lower part of the machine tool, on the level of steering panel of the tested machine tool (Fig. 11). The level of noise in this range equalled $74 \mathrm{dBA}$ (Fig. 12). In the frequency range $3.5 \div 7 \mathrm{kHz}$ the emitted noise came from the gaps between the door and the machine tool's case, and its source is

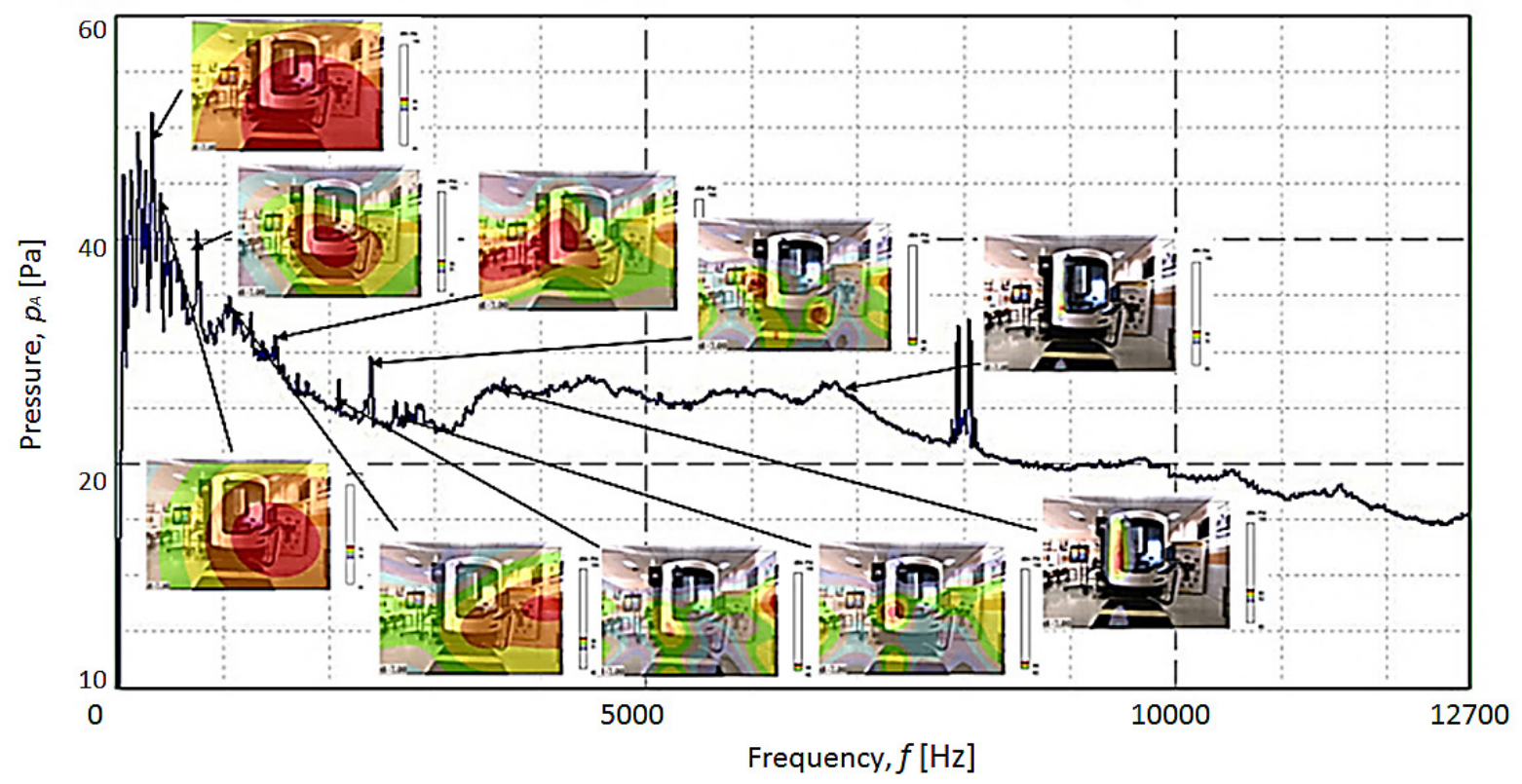

Fig. 15. Set of results of the acoustic holography analysis of the DMU 65 Mono Block milling machine in narrow bandwidths 
the physical process of milling, mechanisms transmitting drive and the belt chip management system. Figures 10 and 15 present detailed analysis of the sound field emitted by the tested machine tools in narrow frequency ranges.

Measurements of the noise emission level in the DMC 635eco workstation revealed the acceptable level of noise overrun in the workstation (85 dBA). In case of a long stay of the machine tool operator in the workstation, the individual hearing protection should be implemented.

\section{REFERENCES}

1. Acoustic holography. User book.

2. Booth R.T.: Risk Assessment Workbook. Aston University, Birmingham, 1989.

3. Bryła R.: Ocena ryzyka zawodowego na stanowisku obróbki skrawaniem metali. Stal, Metale, Nowe Technologie, 2007, 5-6.

4. Hald J.: Basic theory and properties of statistically optimized near-field acoustical holography, J. Acoust. Soc. Am, 125 (4), 2009, 2105-2120.

5. Jacobsen F., Liu Y.: Near field acoustic holography with particle velocity transducers, J. Acoust. Soc. Am., 118 (5), 2005, 3139-3144.

6. Jemielniak K., Kosmol J.: Tool and Process Monitoring - State of Art and Future Prospects. Scientific Papers of the Inst. of Mech. Engng. and Automation of the Technical Univ. of Wroclaw, 61, 1995, 90-112.

7. Jemielniak K., Obróbka wysokoczęstotliwościowych sygnałów emisji akustycznej pochodzącej z procesu skrawania. Postępy Technologii Maszyn i Urządzeń, 18 (4), 1994, 21-29.

8. Józwik J., Pietras P., Investigation and assessment of occupational risk on the metal cutting machine tool stand. Advances in Science and Technology Research Journal, 7 (20), 2013, 47-54.

9. Kossakowska J., Bombiński S., Jemielniak K., System of tool state monitoring ADONiS 10. Mechanik, 12, 2015, 25-28.

10. Krolczyk G., Legutko S., Raos P. Cutting wedge wear examination during turning of duplex stainless steel, Tehnički Vjesnik - Technical Gazette, 20(3), 2013, 413-418.

11. Lind N., Tolerable risk. International Conference on Safety, Risk and Reliability Trends in Engineering. IABSE, Malta 2001, Conference Report, ETH-Hönggerberg, Zürich, 2001.

12. Marchuk V.I., Ravenets L.M., Marchuk S.V., Świć A., Mechanism of origin of structural vibrations in conical roller bearings. Advances in Science and Technology Research Journal, 8 (23), Sept. 2014, 68-72.
13. Maruda R., Legutko S., Krolczyk G., Hloch S., Michalski M.: An influence of active additives on the formation of selected indicators of the condition of the Z10CrNi18-8 stainless steel surface layer in MQCL conditions. Int. J. Surf. Sci. Engin., 9(5), 2015, 452-465.

14. Maruda R., Feldshtein E., Legutko S., Królczyk G.: Research on emulsion mist generation in the conditions of Minimum Quantity Cooling Lubrication (MQCL), Tehnicki Vjesnik - Technical Gazette, 22(5), 2015, 1213-1218.

15. Maynard J.D., Williams E.G., Lee Y.: Nearfield acoustic holography I: Theory of generalized holography and the development of NAH. J. Acoust. Soc. Am, 78(4), 1985, 1395-1413.

16. Norma PN-EN ISO 14121-1:2008. Maszyny. Bezpieczeństwo. Zasady oceny ryzyka.

17. Norma PN-N-01307:1994. Hałas. Dopuszczalne wartości hałasu $\mathrm{w}$ środowisku pracy. Wymagania dotyczące wykonywania pomiarów.

18. Norma PN-N-18001:2004. System zarządzania bezpieczeństwem i higiena pracy. Wymagania.

19. Norma PN-N-18002:2000. System zarządzania bezpieczeństwem i higiena pracy. Ogólne wytyczne do oceny ryzyka zawodowego.

20. Projekt normy PN IEC 60300-3-9:2004. Zarządzanie niezawodnością. Przewodnik zastosowań. Analiza ryzyka w systemach technicznych.

21. Romanowska-Słomka I. Ryzyko zawodowe - procedury, metody, zagrożenia, Wrocław, 2006.

22. Romanowska-Słomka I., Słomka A., Zarządzanie Ryzykiem Zawodowym. Tarnobus Sp. z o.o. Tarnobrzeg, 2001.

23. Sean F. Wu., The helmholtz equation least squares method: For reconstructing and predicting acoustic radiation. Mod. Acoust. Sign. Proc., 2015.

24. Smoliński D., Ocena ryzyka zawodowego na stanowisku pracy - poradnik, Wrocław, 2001.

25. Stec D., Zasady BHP w praktyce, Kraków, 2009.

26. Tokarz W. Zarządzanie bezpieczeństwem pracy. Ocena ryzyka zawodowego. Zał. 4F. Wyd. FORUM, Poznań, 2009.

27. Veronesi W.A., Maynard J.D., Nearfield acoustic holography (NAH) II. Holographic reconstruction algorithms and computer implementation. J. Acoust. Soc. Am., 81(5), 1987, 1307-1322.

28. Werner K. Ocena ryzyka zawodowego na stanowisku tokarza. Przyjaciel przy pracy, 6, 2009, 22-23.

29. Williams E.G., Fourier acoustics-sound radiation and nearfield acoustic holography. Academic Press, 1999.

30. Wojciechowski S., Chwalczuk T., Twardowski P., Krolczyk G.M. Modeling of cutter displacements during ball end milling of inclined surfaces. Archives of Civil and Mechanical Engineering, 15 (4), 2015, 798-805. 